\title{
KADAR GLIAL FIBRILLARY ACIDIC PROTEIN SERUM TINGGI SEBAGAI FAKTOR RISIKO NYERI NEUROPATIK PADA KUSTA TIPE MULTIBASILER
}

\author{
HIGH GLIAL FIBRILLARY ACIDIC PROTEIN SERUM LEVEL AS A RISK FACTOR OF \\ NEUROPATHIC PAIN IN MULTIBACILARY TYPE LEPROSY
}

Sofyan Faridi,* I Made Oka Adnyana, * I Putu Eka Widyadharma, * Luh Made Mas Rusyati**

\begin{abstract}
Introduction : Leprosy is one of the most common causes of non-traumatic peripheral neuropathy in the world. There are many factors causing neuropathic pain in multibacillary (MB) type leprosy, one of which is an increase in serum levels of glial fibrillary acidic protein (GFAP).

Aim: To prove high serum GFAP levels is a risk factor for neuropathic pain in MB type leprosy in Sanglah General Hospital Denpasar.

Methods: This study was an observational analytic study with a case control design conducted at the DermatoVenerology Department outpatient and in Pathological Clinic Laboratory in Sanglah General Hospital from November 2019 to January 2020. The sample of this study is all multibacillary leprosy patients with neuropathic pain who met inclusion criteria. A total of 60 patient were willing to participate in this study, the pain scales were measured using DN4 questionnaire and GFAP serum levels were examined. Chi-square test was performed to prove high serum GFAP levels is a risk factor of neuropathic pain in multibacillary leprosy.

Results: High serum GFAP levels increase the incidence of neuropathic pain of MB type leprosy 5 times higher than controls (OR 5.72; $p=0.003)$, anxiety (OR 2.1; $p=0.24)$, and leprosy reaction (OR 2.2; $p=0.052)$.

Discussion: High serum levels of GFAP is a risk factor of neuropathic pain in MB type leprosy in Sanglah General Hospital Denpasar.
\end{abstract}

Keywords: GFAP, MB type leprosy, neuropathic pain

\section{ABSTRAK}

Pendahuluan: Kusta merupakan salah satu penyebab paling umum neuropati perifer non traumatik di seluruh dunia, yang sudah dikenal sejak lama. Terdapat berbagai faktor resiko nyeri neuropatik pada kusta tipe multibasiler (MB), yang salah satunya adalah peningkatan kadar serum glial fibrillary acidic protein (GFAP) Rumah Sakit Umum Pusat (RSUP) Sanglah Denpasar.

Tujuan: Penelitian ini bertujuan untuk membuktikan kadar GFAP serum tinggi sebagai faktor risiko nyeri neuropatik pada kusta tipe MB.

Metode: Penelitian ini menggunakan rancangan kasus kontrol yang dilakukan di Poliklinik Kulit dan Kelamin RSUP Sanglah dan Instalasi Laboratorium Patologi Klinik RSUP Sanglah Denpasar periode November 2019 - Januari 2020. Sampel dari penelitian ini adalah seluruh penderita kusta tipe MB dengan nyeri neuropatik yang memenuhi kriteria inklusi. Sebanyak 60 orang penderita kusta tipe MB dilakukan penilaian skala nyeri neuropatik dengan kuesioner DN4, kemudian subjek dilakukan pemeriksaan kadar GFAP serum. Analisis statistic menggunakan uji Chi-square untuk membuktikan kadar GFAP serum sebagai factor risiko nyeri neuropatik pada kusta tipe MB.

Hasil: Kadar GFAP serum tinggi meningkatkan kejadian nyeri neuropatik kusta tipe MB 5 kali lebih tinggi dibandingkan kontrol (RO 5,72; $\mathrm{p}=0,003$ ), ansietas ( $\mathrm{RO} 2,1 ; \mathrm{p}=0,24)$, dan reaksi kusta ( $\mathrm{RO} 2,2 ; \mathrm{p}=0,052$ ).

Diskusi: Kadar GFAP serum tinggi merupakan faktor risiko nyeri neuropatik pada kusta tipe MB di Sanglah Denpasar.

Kata kunci: GFAP, kusta MB, nyeri neuropatik

*Departemen Neurologi, Fakultas Kedokteran, Universitas Udayana, RSUP Sanglah Denpasar, Bali, Indonesia. ** Departemen Dermatovenereologi, Fakultas Kedokteran, Universitas Udayana, RSUP Sanglah Denpasar, Bali, Indonesia. Korespondensi: sofyanfaridi84@gmail.com

\section{PENDAHULUAN}

Kusta atau yang dikenal dengan nama lepra atau Morbus Hansen adalah penyakit menular kronis yang disebabkan oleh Mycobacterium leprae ( $M$. leprae) yang menyerang kulit dan saraf tepi. Kusta merupakan salah satu penyebab paling umum neuropati perifer non traumatik di seluruh dunia, yang sudah dikenal sejak dahulu kala. ${ }^{1}$ Menurut data 
dari Kementerian Kesehatan Indonesia tahun 2018, angka prevalensi kusta di Indonesia pada tahun 2018 adalah 0,71/10.000 penduduk, dengan jumlah kasus baru di Indonesia pada tahun 2017 adalah 15.920 kasus. $^{2}$

Kusta mengakibatkan kerusakan jaringan saraf irreversibel yang menyebabkan cacat pada tangan, kaki, wajah, dan mata serta kehilangan fungsi saraf permanen. ${ }^{3}$ Kerusakan pada demielinasi segmental dan demielinasi aksonal akan menyebabkan nyeri neuropatik, yang digambarkan seperti rasa terbakar, tersengat listrik, nyeri tertusuk, nyeri sayatan, dan kesemutan. ${ }^{4-6}$ Glial fibrillary acidic protein (GFAP) merupakan protein khusus yang terdapat pada sel Schwann (SC) tidak bermielin. GFAP memiliki peran penting dalam regenerasi sel saraf dan proliferasi SC pada sistem saraf tepi yang mengalami kerusakan atau cedera. GFAP diekspresikan dalam filamen intermediet astroglia pada SC tidak bermielin yang terletak di sekitar akson. ${ }^{7}$

Proses degenerasi aksonal yang menyebabkan SC kehilangan kontak dengan akson, kemudian berdiferensiasi dan kembali memasuki siklus proliferasi sel sehingga terjadi perkembangan embrionik pada permukaan molekul serta terjadi peningkatan regulasi sitoskeletal seperti GFAP, kemudian GFAP dari SC dilepaskan dalam kompartemen cairan yang berdekatan sehingga terdeteksi dalam serum. ${ }^{7}$ Penelitian kadar serum GFAP pernah diteliti oleh Notturno dkk. (2009), bahwa kadar serum GFAP meningkat pada pasien dengan neuropati kronis jika dibandingkan dengan kontrol. ${ }^{8}$

\section{TUJUAN}

Tujuan dari penelitian ini adalah untuk membuktikan kadar GFAP serum tinggi sebagai faktor risiko nyeri neuropatik pada penderita kusta tipe MB.

\section{METODE}

Penelitian ini menggunakan rancangan kasus kontrol yang dilakukan di Poliklinik Kulit dan Kelamin RSUP Sanglah dan Instalasi Laboratorium Patologi Klinik RSUP Sanglah Denpasar periode November 2019 - Januari 2020. Sampel penelitian adalah penderita kusta tipe MB yang dengan nyeri neuropatik yang memenuhi kriteria inklusi dan bersedia ikut serta dalam penelitian. Sebanyak 60 orang penderita kusta tipe MB yang berpartisipas, kelompok subjek yang mengalami nyeri neuropatik dikelompokkan sebagai kasus sebanyak 30 orang dan subjek tanpa nyeri neuropatik dikelompokkan sebagai kontrol sebanyak 30 orang. Dilakukan penilaian skala nyeri neuropatik dengan kuesioner DN4, kemudian subjek dilakukan pemeriksaan kadar GFAP serum. Variabel bebas dalam penelitian adalah kadar GFAP serum tinggi, sementara variabel terikat dalam penelitian ini adalah nyeri neuropatik. Penelitian ini sudah mendapatkan surat keterangan etik yang diterbitkan oleh Penelitian Fakultas Kedokteran Universitas Udayana / Rumah Sakit Umum Pusat Sanglah Denpasar dengan nomor 2801/ UN14.2.2.VII.14/LP/2019.

Kriteria inklusi yang ditetapkan adalah pasien kusta tipe MB usia 20-50 tahun, yang didiagnosis antara 1 sampai 5 tahun, menderita nyeri neuropatik, dan bersedia ikut serta pada penelitian ini. Sementara kriteria eksklusi adalah pasien dengan penyakit yang mempengaruhi kadar GFAP dan keadaan yang menyebabkan nyeri neuropatik seperti riwayat stroke, riwayat cidera kepala sedang sampai berat, riwayat trauma medula spinalis, riwayat sindroma Guilain Barre, riwayat multipel sklerosis, riwayat HIV, riwayat keganasan, riwayat diabetes melitus dengan neuropati.

Hubungan antara kadar GFAP serum sebagai variabel bebas dengan nyeri neuropatik sebagai variabel tergantung dinilai dengan menggunakan analisis bivariat. Data dianalisis dengan menggunakan program SPSS for Windows versi 20. Uji hipotesis yang digunakan adalah Chi-square, didapatkan nilai rasio Odds (RO) dengan interval kepercayaan (IK) $95 \%$ dan kemaknaan ditetapkan pada nilai probabilitas $\mathrm{p}<0,05$.

Penelitian ini juga mencari hubungan antara nyeri neuropatik pada penderita kusta tipe MB dengan variabel-variabel lain yang mungkin berpengaruh. Pada penelitian ini dilakukan pula analisis bivariat antara nyeri neuropatik pada kusta tipe MB dengan 
ansietas dan reaksi kusta. Variabel ansietas dan reaksi kusta tidak bermakna secara statistik. Uji hipotesis yang digunakan adalah uji komparatif kategorik tidak berpasangan dengan metode uji Fisher karena ada sel yang mempunyai expected $<5$ sehingga tidak memenuhi syarat dengan metode Chi-square. Ukuran kekuatan diketahui dengan nilai, kemaknaan ditetapkan pada nilai probabilitas $\mathrm{p}<0,05$.

\section{HASIL}

Karakteristik dasar subjek penelitian disajikan pada Tabel 1. Pada kelompok kasus maupun kontrol memiliki rerata umur $36,5 \pm 10$ tahun. Jumlah subjek penelitian berjenis kelamin laki-laki sebanyak 39 orang $(65 \%)$ dan perempuan sebanyak 21 orang (35\%). Rerata lama subjek menderita kusta tipe MB kelompok kasus 1,82 $\pm 0,23$ tahun dan kelompok kontrol 1,92 $\pm 0,29$ tahun. Rerata kadar serum GFAP pada kelompok kasus $3,7 \pm 1,17 \mathrm{ng} / \mathrm{mL}$ dan pada kelompok kontrol 0,74 $\pm 0,21 \mathrm{ng} / \mathrm{mL}$.

Tabel 1. Karakteristik Dasar Subjek Penelitian $(\mathbf{n}=60)$

\begin{tabular}{|c|c|c|}
\hline Profil Demografis & $\begin{array}{l}\text { Kasus } \\
\text { n }(\%)\end{array}$ & $\begin{array}{c}\text { Kontrol } \\
\text { n (\%) }\end{array}$ \\
\hline Usia (tahun), Rerata \pm SD & $36,5 \pm 10$ & $36,5 \pm 10$ \\
\hline \multicolumn{3}{|l|}{ Jenis Kelamin } \\
\hline - Laki-laki & $19(63,3)$ & $20(66,7)$ \\
\hline - Perempuan & $11(36,7)$ & $10(33,3)$ \\
\hline $\begin{array}{l}\text { Lama Menderita (tahun), } \\
\operatorname{Rerata} \pm \text { SD }\end{array}$ & $1,82 \pm 0,23$ & $1,92 \pm 0,29$ \\
\hline $\begin{array}{l}\text { Kadar Serum GFAP }(\mathbf{n g} / \mathbf{m L}) \text {, } \\
\text { Rerata } \pm \text { SD }\end{array}$ & $3,7 \pm 1,17$ & $0,74 \pm 0,21$ \\
\hline
\end{tabular}

SD: standar deviasi; GFAP: glial fibrillary acidic protein.

Dari penelitian ini didapatkan kadar GFAP serum tinggi secara bermakna meningkatkan risiko 5 kali mengalami nyeri neuropatik dibandingkan dengan kadar GFAP normal (RO 5,72; $\mathrm{p}=0,003$ ). Hasil analisis bivariat ditunjukkan pada Tabel 2.

Hasil analisis bivariat variabel lainnya terhadap nyeri neuropatik pada penderita kusta tipe MB dapat dilihat di Tabel 3.
Tabel 3. Analisis Bivariat Faktor Lain dengan Nyeri Neuropatik $(n=60)$

\begin{tabular}{|c|c|c|c|c|}
\hline & $\begin{array}{l}\text { Kasus } \\
\text { n (\%) }\end{array}$ & $\begin{array}{c}\text { Kontrol } \\
\text { n (\%) }\end{array}$ & $\begin{array}{c}\text { RO } \\
\text { (IK 95\%) }\end{array}$ & $p^{*}$ \\
\hline \multicolumn{5}{|l|}{ Ansietas } \\
\hline - Ya & $3(10)$ & $0(0)$ & 2,1 & 0,24 \\
\hline - Tidak & $57(90)$ & $30(100)$ & $(1,6-2,78)$ & \\
\hline \multicolumn{5}{|c|}{ Reaksi Kusta } \\
\hline - Ya & $5(40)$ & $0(0)$ & 2,2 & 0,052 \\
\hline - Tidak & $95(60)$ & $30(100)$ & $(1,65-2,94)$ & \\
\hline
\end{tabular}

Variabel-variabel yang dimasukkan pada analisis multivariat adalah kelompok ansietas, reaksi kusta dan kadar GFAP serum yang pada analisis bivariat didapatkan nilai $\mathrm{p}<0,25$. Berdasarkan hasil analisis multivariat didapatkan bahwa faktor risiko independen terhadap kejadian nyeri neuropatik pada kusta tipe MB adalah kadar GFAP serum dengan RO $7(1,99-24,6 ; \mathrm{p}=0,002)$.

\section{PEMBAHASAN}

Pada penelitian ini, penderita dengan GFAP serum tinggi sebanyak 21 orang yang terbagi dalam kelompok kasus sebanyak 16 orang $(53,3 \%)$ dan kelompok kontrol sebanyak 5 orang (16,7\%). Pada penelitian ini ditemukan jumlah penderita laki-laki lebih banyak dibanding perempuan. Hal ini sesuai dengan studi oleh Giesel dkk (2018) dan Raicher dkk (2018), yang menemukan bahwa jumlah penderita laki-laki lebih banyak menderita nyeri neuropatik pada kusta tipe MB disebabkan karena prevalensi laki-laki terkena kusta lebih banyak dibandingkan perempuan..$^{8,9}$ Kelompok kasus pada penelitian ini mempunyai lama menderita rata-rata 1-2 tahun sedangkan kelompok kontrol 1 sampai $>$ 2 tahun, penelitian ini sesuai dengan penelitian yang dilakukan oleh Haroun (2015) didapatkan penderita kusta tipe $\mathrm{MB}>1$ tahun lebih banyak mengalami nyeri neuropatik dibandingkan yang menderita $>2$

Tabel 2. Analisis Bivariat Kadar GFAP Serum Tinggi dengan Nyeri Neuropatik pada Kusta Tipe MB (n=60)

\begin{tabular}{lcccc}
\hline Kadar GFAP Serum & $\begin{array}{c}\text { Kasus } \\
\mathbf{n}(\mathbf{\%})\end{array}$ & $\begin{array}{c}\text { Kontrol } \\
\mathbf{n}(\mathbf{\%})\end{array}$ & $\begin{array}{c}\text { RO } \\
(\mathbf{I K ~ 9 5 \% )}\end{array}$ & $\mathbf{p}^{*}$ \\
\hline Tinggi $(>0,63 \mathrm{ng} / \mathrm{mL})$ & $16(53,3)$ & $5(16,7)$ & 5,72 & 0,003 \\
Normal & $14(46,7)$ & $25(83,3)$ & $(1,72-18,94)$ & \\
\hline
\end{tabular}

*Uji Chi-square; IK: indeks kepercayaan; RO: rasio Odds; GFAP: glial fibrillary acidic protein. 
tahun disebabkan karena nyeri neuropatik biasanya terjadi setelah mendapatkan terapi multidrug therapy (MDT) secara lengkap sesuai peraturan WHO selama 12-18 bulan, setelah mendapatkan terapi multidrug therapy (MDT) bisa terjadi kambuh berulang (relaps) karena multiplikasi basil persisten yang disebabkan oleh resistensi obat, reaksi kusta atau infeksi berulang. ${ }^{10}$ Berdasarkan analisis bivariat antara kadar GFAP serum dan nyeri neuropatik pada kusta tipe MB dengan kadar GFAP serum tinggi secara bermakna meningkatkan risiko 5 kali mengalami nyeri neuropatik dibandingkan penderita dengan kadar GFAP serum normal. GFAP adalah protein asam sitoskeletal yang tidak larut dan termasuk ke dalam protein filamen menengah kelas III yang terdiri dari 432 asam amino dengan berat molekul 49,8 kDa yang terdapat di sel astrosit sistem saraf pusat (SSP) dan SC tidak bermielin di sistem saraf tepi (SST). Aktivasi GFAP dan induksi protein memainkan peran penting dalam aktivasi sel astroglia setelah terjadi cedera saraf dan degenerasi aksonal pada SC tidak bermielin, maka akan terjadi peningkatan ekspresi GFAP pada neuropati aksonal dan pasien dengan degenerasi aksonal berat memiliki ekspresi GFAP yang lebih tinggi daripada pasien dengan neuropati demielinasi. ${ }^{7,8}$ Walaupun secara proses patofisiologi diduga terdapat keterkaitan antara GFAP dan nyeri neuropatik pada kusta tipe $\mathrm{MB}$, namun studi yang meneliti hubungan keduanya masih terbatas.

Analisis bivariat menunjukkan bahwa kadar GFAP serum tinggi memiliki risiko terjadinya nyeri neuropatik. Faktor lain yang berpengaruh terhadap nyeri neuropatik ialah depresi, ansietas, dan reaksi kusta. Pada penelitian ini tidak didapatkan subjek yang mengalami depresi, subjek yang mengalami ansietas sebanyak 3 (10\%) orang pada kelompok kasus dan tidak didapatkan pada kelompok kontrol. Subjek dengan ansietas tidak dijumpai adanya hubungan yang bermakna secara statistik dalam analisis bivariat dengan $(\mathrm{p}=0,24)$. Penelitian yang dilakukan oleh Kosson dkk. (2018) di Polandia dari 41,56\% subjek dengan nyeri neuropatik, 32,39\% pasien mengalami ansietas dan 17, 85\% pasien mengalami depresi yang dihitung menggunakan Hospital Anxiety and Depression Scale-Modified Version (HADS-M). ${ }^{13}$
Ansietas dan depresi pada penderita kusta dapat terjadi secara multifaktorial akibat stigma buruk di masyarakat, gangguan penampilan akibat lesi kulit, durasi pengobatan yang lama, rasa nyeri, reaksi kusta yang berulang, maupun akibat adanya kecacatan atau disabilitas akibat komplikasi kusta. Pasien kusta yang mengalami ansietas dan depresi akan lebih mudah mengalami nyeri neuropatik akibat dari sistem imun yang menurun dan mempengaruhi kualitas hidup.

Cedera saraf yang mengakibatkan neuropati pada kusta tipe MB menyebabkan degenerasi aksonal dan dorsal root ganglion (DRG) memicu reaktivitas astrosit. Aktivasi astrosit meningkatkan adenosine triphosphate (ATP) dan neuropeptida, menginduksi tumor necrosis factor alpha (TNF $\alpha)$ dari jalur c-jun n-terminal kinase (JNK) secara persisten, basic fibroblast growth factor (bFGF) dan matrix metalloproteinase-2 (MMP-2). ${ }^{9}$ Terjadi pelepasan monocyte chemoattractant protein-1 (MCP-1) \& Interleukin (IL)-1 $\beta$ yang meningkatkan pelepasan glutamat dan terjadi peningkatan GFAP akibat inflamasi serta peningkatan aktivitas neuron melalui reseptor $N$-methyl-D-aspartate (NMDA) yang menghambat reseptor gamma aminobutyric acid (GABA) dan glisin sehingga terjadi nyeri neuropatik. ${ }^{9-11}$ Kelebihan dari penelitian ini adalah menggunakan subjek yang homogen, sehingga penyimpangan akibat perbedaan kadar GFAP serum dapat lebih diantisipasi dan menggunakan instrumen uji realibilitas dan validitas yang tinggi di Indonesia. Kelemahan dari penelitian ini adalah sulitnya memastikan lama subjek menderita kusta tipe MB.

\section{KESIMPULAN}

Penderita kusta tipe MB dengan kadar GFAP serum tinggi lebih berisiko mengalami nyeri neuropatik dibandingkan dengan kadar GFAP serum normal. Dengan mengetahui GFAP serum tinggi sebagai faktor risiko nyeri neuropatik pada kusta tipe MB, obat-obat penghambat aktivitas astrosit dapat dipertimbangkan sebagai pencegahan maupun pengobatan nyeri neuropatik.

\section{DAFTAR PUSTAKA}

1. Bratschi MW, Steinmann P, Wickenden A, Gillis TP. Current knowledge on Mycobacterium leprae transmission: a systematic literature review. Lepr 
Rev. 2015 Jun;86(2):142-55.

2. Kementerian Kesehatan Republik Indonesia. Kusta masih ada di Indonesia. 2018 [cited 2020 Sep 24]; Available from: https://www.kemkes.go.id/article/ view/18013100003/kusta-masih-ada-di-indonesia. html

3. Ploemacher T, Faber WR, Menke H, Rutten V, Pieters T. Reservoirs and transmission routes of leprosy; A systematic review. PLoS Negl Trop Dis. 2020;14(4):e0008276.

4. Oo YM, Paez A, Brown R. Leprosy: A rare case of infectious peripheral neuropathy in the United States. IDCases. 2020;20:e00765.

5. Oliveira MF de, Antunes DE, Santos DFD, Goulart IMB. Evaluation of the cutaneous sensation of the face in patients with different clinical forms of leprosy. PloS One. 2019;14(3):e0213842.

6. Price VG. Factors preventing early case detection for women affected by leprosy: a review of the literature. Glob Health Action. 2017 Dec;10(sup2):1360550.

7. Yang Z, Wang KKW. Glial fibrillary acidic protein: from intermediate filament assembly and gliosis to neurobiomarker. Trends Neurosci. 2015;38(6):364-74.

8. Notturno F, Capasso M, Delauretis A, Carpo M, Uncini A. Glial fibrillary acidic protein as a marker of axonal damage in chronic neuropathies. Muscle Nerve. 2009;40(1):50-4.

9. Giesel LM, Pitta IJR, da Silveira RC, Andrade LR, Vital RT, Nery JA da C, et al. Clinical and Neurophysiological Features of Leprosy Patients with Neuropathic Pain. Am J Trop Med Hyg. 2018;98(6):1609-13.

10. Raicher I, Stump PRNAG, Harnik SB, de Oliveira RA, Baccarelli R, Marciano LHSC, et al. Neuropathic pain in leprosy: symptom profile characterization and comparison with neuropathic pain of other etiologies. Pain Rep. 2018;3(2):e638.

11. Haroun OMOH. Neuropathic Pain In Leprosy: Deep Profiling And Stratification Of Patient Groups. London School of Hygiene \& Tropical Medicine; 2015.

12. Treede R-D, Rief W, Barke A, Aziz Q, Bennett MI, Benoliel R, et al. A classification of chronic pain for ICD-11. Pain. 2015 Jun;156(6):1003-7.

13. Giardini AC, Dos Santos FM, da Silva JT, de Oliveira ME, Martins DO, Chacur M. Neural Mobilization Treatment Decreases Glial Cells and Brain-Derived Neurotrophic Factor Expression in the Central Nervous System in Rats with Neuropathic Pain Induced by CCI in Rats. Pain Res Manag. 2017;2017:7429761.

14. Kosson D, Malec-Milewska M, Gałązkowski R, Rzońca P. Analysis of Anxiety, Depression and Aggression in Patients Attending Pain Clinics. Int J Environ Res Public Health. 2018 Dec;15(12):2898.

15. Grau JW, Huang Y-J, Turtle JD, Strain MM, Miranda RC, Garraway SM, et al. When Pain Hurts: Nociceptive Stimulation Induces a State of Maladaptive Plasticity and Impairs Recovery after Spinal Cord Injury. J Neurotrauma. 2017;34(10):1873-90.

16. Finnerup NB, Haroutounian S, Kamerman P, Baron R, Bennett DLH, Bouhassira D, et al. Neuropathic pain: an updated grading system for research and clinical practice. Pain. 2016;157(8):1599-606.

17. Andresen SR, Biering-Sørensen F, Hagen EM, Nielsen JF, Bach FW, Finnerup NB. Pain, spasticity and quality of life in individuals with traumatic spinal cord injury in Denmark. Spinal Cord. 2016 Nov;54(11):973-9. 